\title{
Barium concentration in cast roe deer antlers related to air pollution caused by burning of barium-enriched coals in southern Poland
}

\author{
M. Jabłońska ${ }^{1}$ • M. Kramarczyk ${ }^{1}$ • B. Smieja-Król ${ }^{1}$ (1) • J. Janeczek ${ }^{1}$
}

Received: 18 September 2015 / Accepted: 20 January 2016 / Published online: 28 January 2016

(C) The Author(s) 2016. This article is published with open access at Springerlink.com

\begin{abstract}
Concentrations of $\mathrm{Ba}, \mathrm{Zn}, \mathrm{Pb}, \mathrm{Fe}$, and $\mathrm{Mn}$ were determined by atomic absorption spectroscopy in freshly cast antlers from male roe deer of different ages ( 2 to 4 years old and older than 4 years) collected in Balin near Chrzanów and in the vicinity of Żywiec, S Poland. Barium content ranged from 124 to $196 \mathrm{ppm}$ (mean $165 \mathrm{ppm}$ ) in the Balin 12 samples and from 207 to $351 \mathrm{ppm}$ (mean $287 \mathrm{ppm}$ ) in 3 antlers from Żywiec. The concentration of $\mathrm{Ba}$ was comparable to that of Zn (134-275 ppm, mean $169 \mathrm{ppm})$. Elevated concentrations of $\mathrm{Ba}$ in antlers most probably originated from direct uptake of airborne barite nanocrystals through the respiratory system and/or by digestion of barite-rich dust particles deposited on plants. Burning of Ba-enriched coals is regarded as the principal source of $\mathrm{Ba}$ in the investigated areas inhabited by roe deer. Increased concentrations of $\mathrm{Ba}$ in antlers from the Żywiec area compared to Balin reflect particularly high air pollution caused by coal-burning mostly for domestic purposes combined with an unfavorable topography that impedes efficient air circulation.
\end{abstract}

Keywords Cast antlers $\cdot$ Roe deer · Barium · Biomonitoring · Coal-burning

Responsible editor: Philippe Garrigues

B. Smieja-Król

beata.smieja-krol@us.edu.pl

1 Faculty of Earth Sciences, University of Silesia, Będzińska 60, 41-200 Sosnowiec, Poland

\section{Introduction}

Antlers are the only mammalian bony appendages capable of full regeneration and the fastest growing bones of vertebrates. Roe deer (Capreolus capreolus) initiate antler growth in autumn and antlers mature in early spring after $\sim 130$ days, when the terminal mineralization of the antler bone stops. The skin (velvet) is shed and the so-called hard antlers are exposed. Antlers are retained on the buck's head until autumn when they are cast followed by the immediate regeneration of a new set of antlers (Pielowski 1984; Kierdorf and Kierdorf 2005).

Antlers of various deer species are used as biomonitors for temporal and/or spatial variations in contaminant concentrations in the environment because during their growth they accumulate pollutants (Kierdorf and Kierdorf 2005). Strontium-90, a radionuclide with a half-life of ca. 29 years, was the first isotope studied in antler tissues to assess the environmental impact of radioactive fallout from atmospheric nuclear weapons tests (Hawthorn and Duckworth 1958). Fluoride and lead are the most commonly determined elements in antlers due to their preferred incorporation into the mineral phase of antler bone (e.g., Kardell and Källman 1986; Tataruch 1995; Kierdorf and Kierdorf 2002; 2003; 2005; Pokorny et al. 2004; Pokorny et al. 2009; Jelenko and Pokorny 2010; Sobota et al. 2011). Cd, Zn, Fe, Mn, Cu, Co, $\mathrm{Cr}$, and $\mathrm{Ni}$ have also been determined in antlers (e.g., Sawicka-Kapusta 1978; Medvedev 1995; Purdey 2004; Landete-Castillejos et al. 2012). To our knowledge there are only two reports on Ba concentrations in antlers (Purdey 2004; Kierdorf et al. 2014).

The barium ion is toxic if bioavailable. For example, oral exposure to low-dose Ba can result in severe ototoxicity with degeneration of inner ears in mammals (Ohgami et al. 2012). Barium can potentially cause hypertension in humans (WHO World Health Organization 2004). Fortunately, Ba availability 
is largely limited in the environment due to the high stability of its main salt-barite $\left(\mathrm{BaSO}_{4}\right.$; solubility product, $\mathrm{K}_{\mathrm{sp}}$ of $1.08 \times 10^{-10}$ at $25^{\circ} \mathrm{C}$ ). Still, under certain condition Ba can occur in soluble forms at concentrations much greater than expected from barite solubility (Pluta and Trembaczowski 2001; Smith et al. 2004; Smieja-Król and Bauerek 2015).

In the present study, the concentrations of $\mathrm{Ba}, \mathrm{Zn}, \mathrm{Pb}, \mathrm{Fe}$, and $\mathrm{Mn}$ were determined in roe deer antlers collected in two sites of southern Poland, located in the proximity of Upper Silesia - one of the European largest industrial and urban regions. Elevated concentrations of $\mathrm{Zn}, \mathrm{Pb}, \mathrm{Cd}$, and $\mathrm{Fe}$ in antlers of roe deer were previously documented in Upper Silesian forests (Sawicka-Kapusta 1978). The purpose of this study was to determine whether the large-scale burning of Baenriched coals in Upper Silesia and surroundings is reflected in the Ba concentration in roe deer antlers.

\section{Materials and methods}

Twelve freshly cast antlers from male roe deer of different ages ( 2 to 4 years old and older than 4 years) were collected 2-3 km west of a village (Balin) located between the cities of Jaworzno and Chrzanów, immediately to the east of Upper Silesia. Another three antlers from 2 to 4 year old male roe deer were collected in the forest of the Beskid Żywiecki mountains, 4-5 km south-east from the city of Żywiec. Most of the antlers were collected by local hunters near cultivated food plots in autumn 2009. Antlers overlooked during the autumn sampling campaign were found in spring 2010 after melting of snow cover. No animal was killed or harmed to collect antlers.

Atomic absorption spectroscopy (SOLAAR M6) was used for the determination of $\mathrm{Ba}, \mathrm{Fe}, \mathrm{Mn}, \mathrm{Pb}$, and $\mathrm{Zn}$ in antlers. Samples were homogenized in a mill, dried at $105^{\circ} \mathrm{C}$, then ashed at $550^{\circ} \mathrm{C}$ for $24 \mathrm{~h}$. The digestion was carried out in hot $5 \%$ citric acid in platinum crucibles for 3-4 h. All metal concentrations were corrected for procedural blanks. The quality of the analytical data for $\mathrm{Pb}, \mathrm{Zn}$, and Fe was checked using the standard reference material (NIST 1486 bone meal). The results of metal analyses are presented on a dry weight basis. The limit of detection for $\mathrm{Fe}, \mathrm{Mn}, \mathrm{Pb}$, and $\mathrm{Zn}$ in antlers was $2 \mathrm{ppm}(\mathrm{mg} / \mathrm{kg})$ and for $\mathrm{Ba} 20 \mathrm{ppm}$. Relationships between metals were examined using Spearman rank correlation coefficient at a confidence level $\alpha=0.05$.

\section{Results and discussion}

\section{Metal concentrations in the antlers}

The concentrations of $\mathrm{Ba}, \mathrm{Zn}, \mathrm{Pb}, \mathrm{Mn}$, and $\mathrm{Fe}$ in the analyzed antlers are given in Table 1. Barium content ranges from 124
Table 1 Metal concentrations (ppm, dry weight basis) in roe deer antlers from Balin and the vicinity of Żywiec

\begin{tabular}{llllll}
\hline Locality, deer age (years) & $\mathrm{Ba}$ & $\mathrm{Zn}$ & $\mathrm{Pb}$ & $\mathrm{Fe}$ & $\mathrm{Mn}$ \\
\hline Balin, 2-4 & 144 & 166 & $<2.0$ & 155 & 4.2 \\
Balin, 2-4 & 178 & 175 & $<2.0$ & 133 & 17.9 \\
Balin, 2-4 & 196 & 275 & 4.2 & 183 & 43 \\
Balin, 2-4 & 175 & 164 & $<2.0$ & 171 & 42.2 \\
Balin, 2-4 & 173 & 129 & $<2.0$ & 106 & 5.8 \\
Balin, >4 & 141 & 149 & 5.2 & 145 & 5.7 \\
Balin, >4 & 167 & 170 & $<2.0$ & 157 & 16.5 \\
Balin, >4 & 124 & 162 & $<2.0$ & 142 & 6.2 \\
Balin, >4 & 150 & 154 & $<2.0$ & 135 & 8.2 \\
Balin, >4 & 166 & 154 & $<2.0$ & 213 & 27.9 \\
Balin, >4 & 182 & 187 & 12.3 & 553 & 17.5 \\
Balin, >4 & 182 & 163 & 14.5 & 111 & 13.7 \\
Żywiec, 2-4 & 207 & 202 & 6.5 & 425 & 63 \\
Żywiec, 2-4 & 351 & 134 & $<2.0$ & 99 & 37 \\
Żywiec, 2-4 & 302 & 155 & $<2.0$ & 97 & 2.0 \\
\hline
\end{tabular}

to $196 \mathrm{ppm}$ (mean value $165 \mathrm{ppm}$ ) in the Balin samples and from 207 to $351 \mathrm{ppm}$ (mean value $287 \mathrm{ppm}$ ) in antlers from the vicinity of Żywiec (Tab. 1). The concentration of $\mathrm{Ba}$ is comparable to the concentration of $\mathrm{Zn}$. The latter spans the range between 134 and $275 \mathrm{ppm}$, with a mean value of $169 \mathrm{ppm}$. Unlike $\mathrm{Ba}$, there is no marked difference in $\mathrm{Zn}$ concentrations between samples from Balin and Żywiec. The concentration of Fe covers a wide range between 99 and $553 \mathrm{ppm}$. Lead concentration ranges from less than $2.0 \mathrm{ppm}$ to $14.5 \mathrm{ppm}$. Manganese concentrations are scattered over a wide range (2.0-63 ppm), with an average value of $20.7 \mathrm{ppm}$. There is no obvious difference in the measured metals concentrations between deer of different age.

Studies on the distribution of $\mathrm{Ba}$ in mammals, including humans, have shown that $\mathrm{Ba}$ accumulates preferably in bones over soft tissues. The typical Ba content in bones of terrestrial mammals is between $5-30 \mathrm{ppm}$, while concentrations in soft tissues range between 0.1 and $2.5 \mathrm{ppm}$ (dry weight; KabataPendias and Pendias 1999). The investigated antlers are on average (189 ppm) enriched in Ba over six times in respect to the highest reference concentration $(30 \mathrm{ppm})$ in the mammalian bones provided by Kabata-Pendias and Pendias (1999). The higher content of $\mathrm{Ba}$ in antlers, relative to more slowly growing types of bone, can only be partially explained by the rapid incorporation of metals during antlers growth. The maximum Ba concentration of $351 \mathrm{ppm}$ in antlers from the Żywiec area is markedly higher than the maximum value of 280 ppm obtained by Purdey (2004) in antlers of deer thriving in areas affected by chronic wasting decease. The maximum Ba concentration in antlers of North American deer living in areas not affected by chronic wasting decease was 74 ppm (Purdey 2004). High Ba concentrations (255- 
395 ppm, dry weight) were recorded in red deer antlers sampled in the 1980s and early 1990s in western Germany and the Netherlands (Kierdorf et al. 2014).

Concentrations of $\mathrm{Pb}$ (Table 1) are well within a range reported for antlers (4.8-28 ppm) by Sawicka-Kapusta (1978) and bone tissues (4-25 ppm; Kabata-Pendias and Pendias 1999), whereas the highest concentrations of Fe measured during this study ( 425 and $553 \mathrm{ppm}$ ) exceed Fe values typical for bones (5-300 ppm; Kabata-Pendias and Pendias 1999). Zinc preferentially concentrates in muscles (100 $200 \mathrm{ppm}$ ) over bones (50-150 ppm) (Kabata-Pendias and Pendias 1999). Its average content in the antlers (169 ppm) is slightly above the bone range and similar to values (110$180 \mathrm{ppm}$ ) reported by Sawicka-Kapusta (1978) for antlers sampled in Upper Silesia. The Mn content in antlers ranges from 2 to $63 \mathrm{ppm}$ and in six samples (Table 1) its content is 2 to 6 times higher than typically found in bones $(0.2-10 \mathrm{ppm}$; Kabata-Pendias and Pendias 1999). The statistical analysis (Spearman rank correlation) revealed weak positive correlations only between $\mathrm{Fe}$ and $\mathrm{Zn}\left(r_{\mathrm{s}}=0.61 ; p<0.05\right)$ and $\mathrm{Fe}$ and $\mathrm{Mn}\left(r_{\mathrm{s}}=0.53 ; p<0.05\right)$, while concentrations of the other elements were uncorrelated (all $p>0.05$ ).

\section{Sources of barium}

The main source of barium in the antlers from Balin and Żywiec is most probably Upper Silesian coal-burning for both domestic and industrial uses (Różkowska and Ptak 1995; Wójcik and Smołka-Danielowska 2008; Wilczyński 2013). Processing of $\mathrm{Zn}-\mathrm{Pb}$ ores and dust deposition from cement plants might be of some importance in Balin, although these activities have recently been significantly reduced.

Barium is a coalphile element with a coal affinity index $(\mathrm{CAI}=$ average element concentration in coal ash/Clarke value in sedimentary rocks) of 2.3 (Ketris and Yudovich 2009). Barium concentrations in Upper Silesian coals range from 0.2 to $4260 \mathrm{ppm}$ with a mean value of $176 \mathrm{ppm}$ (Różkowska and Ptak 1995), higher than the mean $\mathrm{Ba}$ concentration of
$150 \mathrm{ppm}$ in world coals (Ketris and Yudovich 2009). Accordingly, Ba content in the ash of Upper Silesian coals is almost twice as high (1852 ppm) as the world's mean concentration of $980 \mathrm{ppm}$, resulting in a CAI of 4.5 .

In 2009, the dust emission from coal combustion in Poland amounted to $176,400 \mathrm{Mg}$. Sixty-six percent of that dust was emitted from domestic heating systems (Wilczyński 2013). As a result of such a high dust emission, the threshold value of $40 \mu \mathrm{g} / \mathrm{m}^{3}$ set by the EU for particulate matter (PM10) was significantly exceeded in the antlers' collecting sites during the heating season (Fig. 1). Żywiec and its surroundings particularly suffered from the ineffective coal combustion in domestic heating systems while lacking large industrial emission sources. The problem of air pollution is worsened by the location of the city in a intermontane basin and the resulting impeded air circulation.

Barite nanocrystals (20 to $160 \mathrm{~nm}$ in diameter) are common and abundant in atmospheric dust in and around the region of Upper Silesia (Jablonska et al. 2001). Numerous of these nanocrystals occur within the respirable particles of hydrocarbons that can enter the mammalian respiratory system. In fact, barite particles, $0.42-0.60 \mu \mathrm{m}$ in diameter, were observed in lungs of humans living in Upper Silesia (Jablonska 2013).

\section{Barium incorporation pathways}

Two uptake routes must be considered to explain $\mathrm{Ba}$ accumulation in roe deer antlers, viz. direct uptake through the respiratory system and by digestion. Dermal absorption is not expected to play any significant role. The solubilization of inhaled barite has been demonstrated in numerous studies by clearance of barite from the respiratory system followed by skeletal accumulation and urinary excretion of $\mathrm{Ba}$ (e.g., Morrow et al. 1964; Cuddihy et al. 1974).

The exposure to barium through food ingestion can be of significance only if Ba-enriched dust particles are deposited on plant surfaces. Barite particles were observed on Scots pine (Pinus sylvestris) needles by scanning electron microscopy
Fig. 1 Concentration of airborne particulate matter with the aerodynamic diameter less than $10 \mu \mathrm{m}$ (PM10) at monitoring stations located close to the sampling sites (http://monitoring. katowice.wios.gov.pl/)

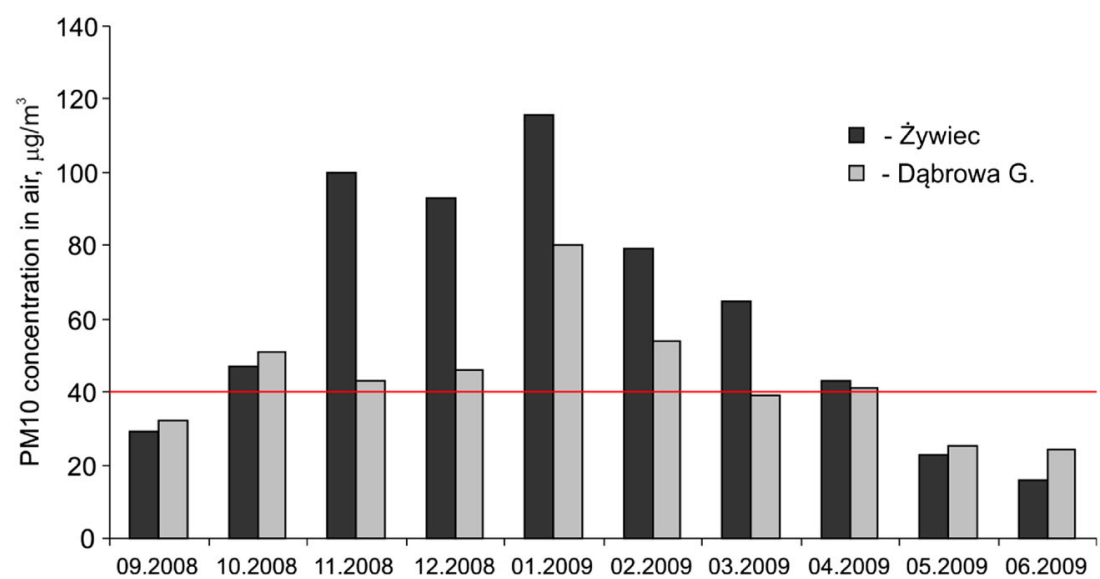


(Teper 2009) as result of wind re-deposition from $\mathrm{Zn}-\mathrm{Pb}$ flotation tailing ponds at a site located $17 \mathrm{~km} \mathrm{NE}$ from Balin.

Barium concentration in soils and its uptake by plants seem to be less important for the Ba accumulation in antlers. Barium concentrations in antlers from the $\dot{Z}$ ywiec area are higher than in antlers from Balin (Table 1), despite the higher Ba content in soils near Balin. Barium concentration in topsoil $(0-30 \mathrm{~cm})$ in Balin ranges from 30 to 240 ppm (Pasieczna 2011); whereas Ba content in topsoil in the vicinity of Żywiec is generally less than 50 ppm (Lis and Pasieczna 1995). While plants are known to accumulate $\mathrm{Ba}$ in their green parts (Kabata-Pendias and Pendias 1999; Gałuszka et al. 2015), and food ingestion was identified as the primary exposure to Ba (ATSDR Agency for Toxic Substances and Disease Registry 2007), this intake route cannot explain the difference in $\mathrm{Ba}$ concentrations in antlers from the Balin and $\dot{Z} y w i e c$ areas.

\section{Conclusions}

Elevated concentrations of $\mathrm{Ba}$ observed in antlers during this study most probably originated from direct uptake of airborne barite nanocrystals through the respiratory system and/or by digestion of barite-rich dust particles deposited on plants. Burning of Ba-enriched coals is the principal source of $\mathrm{Ba}$ in the investigated areas inhabited by roe deer. It is not known if elevated concentrations of $\mathrm{Ba}$ in antlers reflect adverse health effects caused by accumulation of this toxic element in deer as suggested by studies in North America. The mechanism of solubilization of apparently insoluble barite inhaled or ingested by mammals requires further study.

Acknowledgments This study was financially supported by the statutory fund granted to the Faculty of Earth Sciences, University of Silesia, to complete MSc thesis of the second author.

Compliance with ethical standards The authors declare no potential conflicts of interest. The present research did not involve human participants and/or animals.

Open Access This article is distributed under the terms of the Creative Commons Attribution 4.0 International License (http:// creativecommons.org/licenses/by/4.0/), which permits unrestricted use, distribution, and reproduction in any medium, provided you give appropriate credit to the original author(s) and the source, provide a link to the Creative Commons license, and indicate if changes were made.

\section{References}

ATSDR (Agency for Toxic Substances and Disease Registry) (2007) Toxicological profile for barium and compounds (update). Department of Public Health and Human Services, Public Health Service, Atlanta
Cuddihy RG, Hall RP, Griffith WC (1974) Inhalation exposures to barium aerosols: physical, chemical and mathematical analysis. Health Physics 26:405-416

Gałuszka A, Krzciuk K, Migaszewski ZM (2015) A new two-step screening method for prospecting of trace element accumulating plants. Int J Environ Sci Technol 12:3071-3078

Hawthorn J, Duckworth RB (1958) Fall-out radioactivity in a deer's antlers. Nature 182:1294

Jablonska M (2013) Indicative mineral components in lung tissue of persons exposed to aerosol atmospheric contaminations in the Katowice Conurbation (in Polish with English summary). Wydawnictwo Uniwersytetu Śląskiego, Katowice

Jablonska M, Rietmeijer FJM, Janeczek J (2001) Fine-grained barite in coal fly ash from the Upper Silesian Industrial Region. Environ Geol 40:941-948

Jelenko I, Pokorny B (2010) Historical biomonitoring of fluoride pollution by determining fluoride contents in roe deer (Capreolus capreolus L.) antlers and mandibles in the vicinity of the largest Slovene thermal power plant. Sci Total Environ 409:430-438

Kabata-Pendias A, Pendias H (1999) Biogeochemistry of trace elements (in Polish). Warszawa. PWN

Kardell L, Källman S (1986) Heavy metals in antlers of roe deer from two Swedish forests, 1968-1983. Ambio 15(4):232-235

Ketris MP, Yudovich YE (2009) Estimations of Clarkes for carbonaceous biolithes: world averages for trace element contents in black shales and coals. Int J Coal Geol 78:135-148

Kierdorf H, Kierdorf U (2002) Reconstruction of a decline of ambient lead levels in the Ruhr area (Germany) by studying lead concentrations in antlers of roe deer (Capreolus capreolus). Sci Total Environ 296:153-158

Kierdorf U, Kierdorf H (2003) Temporal variation of fluoride concentration in antlers of roe deer (Capreolus capreolus) living in an area exposed to emissions from iron and steel industry, 1948-2000. Chemosphere 52:1677-1681

Kierdorf U, Kierdorf H (2005) Antlers as biomonitors of environmental pollution by lead and fluoride: a review. Eur J Wildl Res 51:137-150

Kierdorf U, Stoffels D, Kierdorf H (2014) Element concentrations and element ratios in antler and pedicle bone of yearling red deer (Cervus elaphus) stags-a quantitative X-ray fluorescence study. Biol Trace Elem Res 162:124-133

Landete-Castillejos T, Estevez JA, Ceacero F, Garcia AJ, Gallego L (2012) A review of factors affecting antler composition and mechanics. Front Biosci E4:2328-2339

Lis J, Pasieczna A (1995) Geochemical map of Poland 1:2 500000. Warszawa, Państwowy Instytut Geologiczny

Medvedev N (1995) Concentrations of cadmium, lead and sulphur in tissues of wild, forest reindeer from north-west Russia. Environ Pollut 90:1-5

Morrow PE, Gibb FR, Johnson L (1964) Clearance of insoluble dust from the lower respiratory tract. Health Physics 10:543-555

Ohgami N, Hori S, Ohgami K, Tamura H, Tsuzuki T, Ohnuma S, Kato M (2012) Exposure to low-dose barium by drinking water causes hearing loss in mice. Neurotoxicology 33:1276-1283

Pasieczna A (2011) Detailed geochemical map of Upper Silesia 1:25 000, sheet Jaworzno, Warszawa.

Pielowski Z (1984) Sarna. Państwowe Wydawnictwo Rolnicze i Leśne; Warszawa.

Pluta I, Trembaczowski A (2001) Changes of the chemical composition of discharged coal mine water in the Rontok Pond, Upper Silesia, Poland. Environ Geol 40:455-457

Pokorny B, Glinšek A, Ribarič-Lasnik C (2004) Roe deer antlers as a historical bioindicator of lead pollution in the Salek Valley, Slovenia. J Atmos Chem 49:175-189

Pokorny B, Jelenko I, Kierdorf U, Kierdorf H (2009) Roe deer antlers as historical bioindicators of lead pollution in the vicinity of a lead smelter, Slovenia. Water Air Soil Pollut 203:317-324 
Purdey M (2004) Elevated silver, barium and strontium in antlers, vegetation and soils sourced from CWD cluster areas: $\mathrm{Do} \mathrm{Ag} / \mathrm{Ba} / \mathrm{Sr}$ piezoelectric crystals represent the transmissible pathogenic agent in TSEs? Medical Hypotheses 63(2):211-225

Różkowska A, Ptak B (1995) Bar w węglach Górnego Śląska. Przegląd Geologiczny 43(3):223-226

Sawicka-Kapusta K (1978) Ocena zawartości metali ciężkich w porożach sarn z lasów śląskich. Archiwum Ochrony Środowiska 1:107-121

Smieja-Król B, Bauerek A (2015) Controls on trace-element concentrations in the pore waters of two Sphagnum-dominated mires in southern Poland that are heavily polluted by atmospheric deposition. $\mathrm{J}$ Geochem Explor 151:57-65

Smith E, Hamilton-Taylor J, Davison W, Fullwood NJ, McGrath M (2004) The effect of humic substances on barite precipitation - dissolution behaviour in natural and synthetic lake waters. Chem Geol 207:81-89

Sobota S, Baranowska-Bosiacka I, Gutowska I, Kupiec M, Dusza K, Machoy Z, Chlubek D (2011) Biomonitoring of lead and fluoride contamination in forests using chemical analysis of hard tissues of roe deer (Capreolus capreolus L.). Pol J Environ Stud 20:435-443

Tataruch F (1995) Red deer antlers as biomonitors for lead contamination. Bull Environ Contam Toxicol 55:332-337

Teper E (2009) Dust-particle migration around flotation tailings ponds: pine needles as passive samplers. Environ Monit Assess 154:383391

WHO (World Health Organization) (2004) Barium in drinking-water. Background document for development of WHO Guidelines for Drinking-water Quality. WHO/SDE/WSH/03.04/76

Wilczyński M (2013) Zmierzch węgla kamiennego w Polsce. Instytut na Rzecz Ekorozwoju, Warszawa

Wójcik M, Smołka-Danielowska D (2008) Phase minerals composition of wastes formed in bituminous coal combustion from individual domestic furnace in the Piekary Śląskie town (Poland). Pol J Environ Stud 17:817-821 